\title{
THE VULNERABILITY OF THE YOUNG TO THE CHALLENGES OF POSTMODERNITY
}

David Pestroiu*

Abstract: Postmodernity - a new paradigm of human existence: between technological progress and spiritual regress. We live in full postmodernism. As we find ourselves surrounded and assisted by cutting-edge technologies, employ fast and effective means of communication, travel easily across the world, we have turned our lives into a comfortable succession of hedonistic experiences. The consumerist society perceives itself as an emancipated one, by virtue of the effects of globalization. Spiritually, the deification of the self has reached paroxistic levels, annihilating any expression of a communitarian status, as promoted by traditional religions. The machine-man, isolated in the cyber-space, creates a space of illusory self-sufficiency, where he takes a critical stance on the real world which he is actually unable to change for the better. The young are the most vulnerable. This is why the present paper aims to identify the causes generating this change in the societal paradigm, as well as the pastoral-missionary remedies put forth by the Orthodox Church in order to re-direct people towards traditional values, in a life of loving communion, according to the ultimate model of the Holy Trinity.

Keywords: postmodernity, mission, youth, emancipation, self, nihilism, secularism, communication, manipulation.

\section{Is emancipation demonic in itself?}

In one of the most troubling definitions given to postmodernity, Paul Lakeland asserts it contains elements both emancipator and demonic ${ }^{1}$. Since the Creation, the destiny given by God to man has been to grow, to evolve, to develop. In the parable of the tares (Matth. 13, 24-30; 36-43), Jesus Christ reiterates this idea, describing the growth of good wheat alongside the weeds, to be

* PhD, Rev., Associate Professor, Justinian Patriarhul Faculty of Orthodox Theology, at University of Bucharest.

${ }^{1}$ Paul Lakeland, Postmodernity: Christian Identity in a Fragmented Age (Guides to Theological Inquiry Series), Minneapolis, Minnesota, Fortress Press, 1997, p. 89. 
separated at the time of the harvest. This raises the question: if God allows good and evil to coexist, so that free will may be exerted, from the beginning to the end of this world, why is only the postmodern society singled out as highly exposed to the demonic influence? Certainly, because now the achievements of science, expressed by advanced technologies, are outstanding, even exceptional in comparison with other historical periods. In other words, the higher the achievements of science and technology, the more ground is gained by atheism, nihilism, secularism, syncretic esotericism, and all other demonic ideologies. As the wheat ripens, tares grow as well.

Regarding the question above, we mention that the progress of humankind is postulated in the first commandment of creation; thus man's emancipation complies with the will of God and is an obvious work of the divine Providence. The evolution of rational knowledge, leading to the development of sciences and technologies, is offered as a gift of God, in the synergy between His uncreated grace and the free will of man. How does the demonic emerge, then? And why does it grow in proportion with the emancipation of society? The answer provided by the Church to these questions speaks of personified evil, instantiated by the evil spirits, who in their turn have diversified their snares (the temptations), by atuning them to the specific traits of today's world.

\section{The abyss of the luciferic fall: idolizing the self}

Today the main temptation from the devil is individualism. Paradoxically, the more communication media develop, covering the entire surface of the earth in interaction networks that abolish distances or language barriers, the lonelier man becomes. Communication seems to be enhanced, but man actually becomes lonely and estranged. LCDs and gadget displays that mimic the human retina are able to render highly detailed images, or instantly convey messages across thousands of kilometres, but cannot 
reproduce the comforting effect of a hug, the warmth of a kiss, the joy felt at the physical presence of a dear person. Man is actually more and more isolated. Feelings are shown increasingly seldom and inter-human relations become increasingly formal. Love has been reduced to mere bodily pleasure, more often than not devoid of any emotional participation.

In this context emerges a new, extremely important direction in confessing Christ: the mission of the Orthodox Church in postmodernity. To the expansion of individualism, the Church must oppose the communitarian life in spiritual love (agape) $)^{2}$, according to the example of the Most Holy Trinity, promoting humility as the foundation of all other virtues. Metrop. Meliton of Chalcedon warns against the danger of alienating theology from life, in the modern era, with the risks it entails:

„Modern man does not listen to or concern himself with theology, because theology has confined itself to academic matters, and has let itself become alienated from the life of mankind. Theology lives and flourishes when the common man is aware of its presence. But the very opposite is the case today. Theology is ignored. It is only a scholarly concern; regrettably, it has become a specialization. It is counted among the sciences, while its true role should be to offer its theologizing to each science, and to provide both man and the world with aims, and with the driving force needed for the fulfilment of those aims. But what happens today? When theology attempts to establish contact with life and play this vital role of hers, it becomes evident that the relationship established is as one with a venerable relic, or else one in which theology tails along behind life, conforming to the world, following the march of events, and frequently ending up as welfare sociology"3.

${ }^{2}$ Mihail Neamţu, Bufniţa din dărâmături; Insomnii teologice în România postcomunistă (An Owl among the Ruins. Theological Insomnias in PostCommunist Romania), 2-nd edition, revised and enhanced, Iaşi, Polirom Publishing House, 2008, p. 60.

${ }^{3}$ Meliton of Chalcedon, The Ecumenical Movement and the Fourth General Assembly of the WCC at Uppsala, in: The Orthodox Church in the Ecumenical 
Secularism, a modern phenomenon, reaches alarming levels in postmodernity. It is much more harmful than atheism, as it is hidden under the guise of the false appearance of religious membership. It is actually a case of believing without belonging ${ }^{4}$. It is much easier to declare your adherence to a religious system, and then criticize it from the inside as unable to reform, than to observe a set of rules seen as backward and restrictive. Any form of institutional religion is thus denied. Traditional belief in God is, most of the times, confined to a mere statement and paid lip service only. The great religious feasts (such as the Lord's Nativity and Resurrection) are turned into mundane events, where gastronomy is the paramount concern, thus encouraging consumerism and a formal exchange of gifts, not as an act of charity but as social interaction motivated by interest, according to the cause-effect pattern. Of late, these special days are celebrated by exotic trips or spent in youthful manner in nightclubs. The only occasions when the secularized man attends the church are the celebrations of baptisms, weddings, funerals - perceived as mere customs, with fewer and fewer participants in the religious service.

Rev. PhD. Prof. Gh. Petraru states: postmodernity proclaims the equality of religions, their source in the human mind and not in the transcendent ${ }^{5}$. Advanced technologies, the mass-media, fast communication and the development of the Internet pose as many challenges. Most of their messages convey criticism and are highly

Movement. Documents and Statements, 1902-1975, edited by Constantin G. Patelos, Geneva, World Council of Churches, 1978, p. 282.

${ }^{4}$ The phrase lent the title of a text by Grace Davie, Religion in Britain Since 1945: Believing without Belonging, Oxford, Institute of Contemporary British History, Blackwell, 1995.

5 Gheorghe Petraru, Teologie fundamentală și misionară. Ecumenism (Fundamental and Missionary Theology. Ecumenism), Iași, Performantica Publishing House, 2006, p. 231. 
manipulative, with the intention of undermining the image of the Church, targeted because of its impact on the society.

\section{Communication or manipulation? The Internet addiction}

We mention that young people are especially vulnerable to destabilizing messages, lacking any ecclesial authority, promoted mainly online on obscure websites, blogs or forums as well as through social networking:

"People who attack Christians online usually do so for a reason. These reasons vary, so it is a good idea to work out what is motivating someone to attack you rather than dismiss the person out of hand. Sometimes people simply enjoy starting fights and upsetting people online, and find Christians are easy to goad into an argument. Others have a dislike of organised religion in general or of Christianity in particular, and will throw some well-worn arguments or criticisms your way without being at all interested in your answer. Some will have had damaging experiences at the hands of other Christians which have left them angry and possibly scarred, and they want someone to hear and acknowledge what they have experienced"6.

Such analysis undertaken by Pam Smith, in her recently published book Online Mission and Ministry, provides the reader with a realistic assessment of the increasingly worrying electronic war against the faith. Here are a few possible solutions, suggested by the same author:

"It depends on your temperament and your reasons for being online how you respond to these challenges. Some people thrive on debate and can participate in lively discussions without feeling emotionally affected. I don't enjoy arguing and can easily become emotionally involved, so I am usually completely open about the fact that I don't

${ }^{6}$ Pam Smith, Online mission and ministry. A theological and practical guide, London/Hong Kong, Society for Promoting Christian Knowledge, Ashford Colour Press, 2015, p. 58. 
enjoy arguments for their own sake and withdraw. It's important to know what your strengths are, and I know that I am much better at dialogue than debate. People who excel at factual, point-by-point debate may find it more difficult to participate in the sort of dialogues I enjoy, where there are no clear winners or losers but an increase in mutual understanding.

If people are aggressive, it's important to try and work out what is behind the aggression (...) In this case, listening and responding empathetically is helpful; arguing that they are wrong to feel as they do, or defending the actions that caused them distress, is more likely to reinforce their distress"

The Church must warn against the enormous danger of online manipulation of the young. Currently, many of them are addicted to the Internet and the social networking. There are strategies aimed precisely at this vulnerable category of persons, insufficiently educated, naive and easily manipulable emotionally, who are comfortable with the misleading safety of message circulation. Belonging to a group of online friends, including colleagues at school or work, neighbours, acquaintances and relatives, creates the risk of disseminating manipulative messages, under the pretext of group cohesion, allegedly functioning as a filter. What actually happens is that many facts or suggestions are circulated and passed down uncritically, with the aim of causing deep changes in the minds of the young ${ }^{8}$. In his book The Church of Facebook, Jesse Rice makes a statement both shocking and true, with respect to the current mentality of the youth: being online is the key to happiness ${ }^{9}$. The young have become utterly addicted to the gadgets providing access

\footnotetext{
${ }^{7}$ Ibidem.

${ }^{8}$ Recent sociological research has shown that the peak times for disseminating information by social networking are 7-8 a.m. and 19-20 p.m.; there is also a database containing the most touching expressions, that elicit the greatest emotional response.

9 Jesse Rice, The Church of Facebook. How the Hyperconnected Are Redefining Community, published by David C. Cook, Colorado Springs, 2009, p. 28.
} 
to the Internet, which they use almost exclusively to join social networking. Here they specialize in a peculiar language, with its own spelling and strewn with emoticons, while communication is encoded, with specific abbreviations and idioms. In this space, Orthodox mission is virtually non-existent, while manipulative messages abound in form and content.

\section{Nihilism: when atheism becomes aggressive}

Postmodern society is a culture medium for anti-Christian, anti-religious attitudes. Whereas in the past, atheism was professed with the restraint and decency necessary to maintaining good social relations, today we witness a regrettable surge of nihilism, with violent manifestations that entail similar reactions. It is now current practice to mock what others hold sacred, to discredit the spiritual values that determine religious knowledge and thought. Postmodernity has set its snares in order to lead today's man away from the revealed teachings, and in exchange offers illusions that justify self-centeredness and hedonism. It is not surprising, then, that society undergoes spiritual regress, as it gives precedence to earthly concerns over eternal life. In this context, the death of God, first theorized by Nietzsche, is further ideologized and spawns the nihilistic concepts of postmodernity ${ }^{10}$. In his excellent study entitled: Mission modernity: seven checkpoints on mission in the modern world, Os Guiness states:

"The Christian church has contributed to the rise of modern world; the modern world, in turn, has undermined the Christian church. Thus, to

\footnotetext{
${ }^{10}$ Carlo Maccari, Aspetti relativistici dello gnosticismo e della „, New Age, in: Il relativismo religioso sul finire del secondo millennio, Gruppo di ricerca e di informazione sulle Sètteretariato per l'ecumenismo e il dialogo della Conferenza episcopale italiana, Citta del Vaticano, Universita Cattolica del Sacro Cuore - Libreria Editrice Vaticana, 1996, p. 195.
} 
the degree that the church enters, engages and employs the modern world uncritically, the church becomes her own gravedigger" ${ }^{\prime 1}$.

After the demise of communism, the Orthodox Churches in the respective countries face a serious problem: a massive number of self-professed adherents, baptised only to comply with tradition, but lacking even a minimal catechetic instruction and never taking part in ecclesial life. Many of them have embraced occult, heretical, demonic or sectarian notions, in addition to the atheist, materialistic ones propagated by the former regime. However, the greatest danger to Orthodox Christians is posed by secularism, which - as postmodern crises multiply - has become entrenched in the globalized society, extremely open to ideologies imported from the West. This phenomenon occurs not only across the former communist territories, but also in the Greek-speaking Orthodox area, as a consequence of excessive ecclesiastical nationalism, which may prevent the correct understanding of the Church role in operating an ontological transformation of human life. In his outstanding study on this topic, Prof. G. Mantzaridis writes:

"If the Orthodox Church settles for a conventional presence and testimonial in the world, if it fails to live up to the contemporary challenge with the universal spirit of Christ and of the Apostles, it will leave the contemporary men helpless and it will succumb as a result of the homogenization promoted through globalization. If, on the other hand, it has the courage to promote, in a self-critical and modest manner, both at the individual, and at the community level, the spirit of its traditions, it could offer the truth of ecumenism in response to the chimera of globalization"12.

${ }^{11}$ Os Guiness, Mission modernity: seven checkpoints on mission in the modern world, in: Philip Sampson, Vinay Samuel, and Chris Sugden (eds.), Faith and Modernity, Oxford, Regnum Books International, 1997, p. 324.

${ }^{12}$ Georgios I. Mantzaridis, Globalizare şi universalitate. Himeră şi adevăr (Globalization and universality. Delusion and truth), Bucharest, Bizantină Publishing House, 2002, p. 180-181. 
The postmodern condition has been masterfully described by J. F. Lyotard, as incredulity toward 'metanarratives "13. The society fosters a general mistrust towards the fundamental values which used to be the vectors of its development. One by one, beliefs, legislative systems, politics, history itself relativize their messages in the minds of the Facebook generation. The past is no longer relevant in managing the present and planning the future. It is regarded as a mere curiosity, with the same mistrust, without any impact on human attitude. Postmodern man wants nothing to do with the past: he lives exclusively in the present. Thus he creates his own set of values, based on the search for pleasure and a consumerist lifestyle, centred on the exaggerated interest in the body and complete disregard for the soul. Those - increasingly few - who still believe in the soul, choose a syncretic combination of Oriental philosophies, encouraging the belief in reincarnation, much more convenient than the Christian doctrine of judgment after death. The young generation, addressed by the present study, is actually indifferent to the matter of eternity, as long as the earthly paradise of this life holds more appeal. In a globalized world, where boundaries are blurred, and the free economic-financial market is encouraged, a cultural and religious hypermarket ${ }^{14}$ has promptly emerged.

In his excellent work A primer on postmodernism, Stanley J. Grenz discusses the actual ways in which Christianity can manage the challenges of postmodernity, as defined by J. F. Lyotard. Under the title: Rejecting the Rejection of the Metanarrative, he provides concrete missionary solutions:

${ }^{13}$ Jean François Lyotard, The Postmodern Condition: a Report on Knowledge, translation from French by Geoff Bennington and Brian Massumi, Foreword by Fredric Jameson, Minneapolis, University of Minnesota Press, 1984, p. XXIV. ${ }^{14}$ World Council of Churches - Mission and Evangelism, Believing without belonging? In search of new paradigms of church and mission in secularised and postmodern contexts, Consultation in Breklum, Northern Germany, 2002 http://www.oikoumene.org/en/resources/documents/commissions/mission-andevangelism/consultation-on-mission-in-secularised-and-postmodern-contexts 
"Contrary to the implications of Lyotard's thesis, we firmly believe that the local narratives of the many human communities do fit together into a single grand narrative, the story of humankind. There is a single meta-narrative encompassing all peoples and all times.

As Christians, we claim to know what that grand narrative is. It is the story of God's action in history for the salvation of fallen humankind and the completion of God's intentions for creation. We boldly proclaim that the focus of this meta-narrative is the story of Jesus of Nazareth, who, we testify, is the incarnate Son, the second Person of the triune God"15.

\section{New ideologies, new movements, new idols of postmodernity}

The multiplication of the new religious movements accounts for the postmodern man's preference for outward religiosity that justifies his hedonistic, consumerist attitude. This explains the success of millenarianist movements, presenting salvation in the guise of an earthly paradise, where the concupiscence experienced in bodily life can be continued. In general, people have ceased to expect the resurrection of the dead, and do not look for the life of the world to come. Recent surveys have demonstrated that, in the secularized West, less than $10 \%$ of the Christians still believe in the afterlife. In Romania, $53 \%$ of citizens declared that they did not wish to live eternally. This is an indicator of the new hedonism of our times. Material welfare creates the misleading belief that human bodily life is indestructible, and thus daily life lacks any kind of preparation for death. On the contrary, people cling to earthly life, attempting in every way avoid the problem: through cosmetic surgery, geriatric treatments and various medical or para-medical procedures, they endlessly delay the answer to this existential question. Thus many are unprepared for the moment of death.

${ }^{15}$ Stanley J. Grenz, A primer on postmodernism, Michigan/Cambridge, U.K., Grand Rapids, William B. Eerdmans Publishing Company, 1996, p. 164. 
Orthodoxy, however, opens the way to the Kingdom of Heaven. The exegesis of biblical texts regarding man's access to heaven, emphasizes the importance attached to Christian charity. This is why Michael Barnes notes that the Kingdom of God can never be reached unless there is a prophetic answer to the plight of the humble ${ }^{16}$.

The major challenge posed by postmodernity, with direct impact on the religious life of the young in today's Romania, is the emergence of a new, autarchic and individualistic anthropological paradigm.

Excessive interest in one's self is the great social problem of postmodernity. It is a radical departure from communitarian life and the solidarity based on Christian love. Rev. Prof. Mihai Himcinschi points out: Young people reject hypocrisy quasi completely, because a new set of values has emerged. In the past, a young person would strive to imitate an ideal role model; today, they find it in themselves ${ }^{17}$. Faced with this problem, the Romanian Orthodox Church has intensified individual catechization, as well as the pastoral guidance of the faithful occasioned by the Mystery of Confession. But it is not only the self that is targeted by the new postmodern idolatry. According to Carmelo Dotolo, under the seduction of the plurality of the sacred ${ }^{18}$ many other things are now idolized: work and professional development; family or some of its members; money and material welfare; political, economic or social ideals; fictions produced by the media or film industry; stars of all fields or even sports - we hear about the football god, for instance, and stadiums temples of the football. The major cause of this state of

\footnotetext{
${ }^{16}$ Michael Barnes, Christian Identity and Religious Pluralism: Religions in Conversation, Nashville, Tennessee, Abingdon Press, 1989, p. 7.

${ }^{17}$ Mihai Himcinschi, Violenţa. O analiză misionară şi teologică (Violence. A missionary and Theological Approach), Alba Iulia, Reîntregirea Publishing House, 2010, p. 145.

${ }^{18}$ Carmelo Dotolo, Un cristianesimo possibile. Tra postmodernità e ricerca religiosa, Brescia, Editrice Queriniana, 2007, p. 135.
} 
affairs is the perception of the world as autonomous which leads to idolizing it, and creates a rift between the transcendence of God and the immanence of the world ${ }^{19}$. Unless we understand, with St Gregory Palamas, that God descends into the world in order to sanctify it with His uncreated energies ${ }^{20}$, and to elevate the world as His mystical body, we will be unable to oppose contemporary idolatries.

Postmodernity also thrives on fake spiritualties, promoted either by esotericisms or syncretisms specific to the new religious movements, or by the revival of occultism. Under the pretext of socalled beneficial effects, superstitions and magic, folk practices, divination of all types - including horoscopes and astrograms - are reinstated. Postmodern man is their victim: he experiences this tragic confusion while claiming that he believes in nothing without material proof. A true hysteria has been created around lotteries, bets, raffles, etc. - all in the hope of obtaining gains without work. Risks, often termed challenges, are everywhere: in business, the stock exchange, even in extreme sports and entertainment. The mentality revealed by such practices denotes, on the one hand, the individualism already mentioned above (the belief that a possible win is perfectly welldeserved, without any sympathy for the many losers $)^{21}$, and on the other hand, the disregard for one's own family or even life (the notion that there is no win without risk, and that life must be lived at the fullest, but exclusively on the bodily, mundane level).

${ }^{19}$ See: David Pestroiu, Misiunea Bisericii Ortodoxe în postmodernitate (The Mission of the Orthodox Church in Postmodernity), in: „Theologia Pontica”, Year II (2009), no. 1, p. 133.

${ }^{20}$ St. Gregory Palamas, Despre lumina şi luminarea dumnezeiască (On divine light and enlightening), in: Dumitru Stăniloae, Viaţa şi învăţătura Sfântului Grigrie Palama (The Life and Teachings of St Gregory Palamas), Bucharest, The Biblical and Missionary Institute of the Romanian Orthodox Church Publishing House, 2006, p. 323.

${ }^{21}$ David Pestroiu, op. cit., p. 134. 
Christ's redeeming work is seen by the postmodern man as a pointless sacrifice, because sin has been completely relativized. Autarchy, the highest degree of pride, leads to spiritual blindness by which man justifies his every action, invoking the rights and liberties he deserves ${ }^{22}$. In such a perspective, moral acts are merely the expression of ethical norms which cannot transform or touch man. He feels responsible only for his own comfort in earthly life. Thus, he deems himself to be infallible and sees no point in the sacrifice on the Cross ${ }^{23}$. Hedonistic lifestyle - a consequence of consumerism prompts his radical reaction to suffering, by claiming his right to assisted suicide or euthanasia. Today, as P. Lakeland shows, we contemplate a strange landscape including poststructuralists, deconstructionists, theorists of the chaos and advocates of entropy, all fighting for conceptual or metaphorical supremacy, over the complex world of our days ${ }^{24}$.

Proclaiming Christ to this type of new culture, marked by agnosticism, is the main challenge in preaching the Gospel today ${ }^{25}$.

Regrettably, secular influence also impacts religious education. After almost 50 years of communism, the study of religion has been reintroduced in Romanian public schools at all levels. It was a moral compensation, as well as a chance to grant children and teenagers access to the values of faith. Gradually, however, more and more pressure is put in order to remove religious education from schools. It has been objected, wrongly, that teaching religion by representatives of various denominations turns this

\footnotetext{
${ }^{22}$ For details, see: G. Marco Salvati, Relativismo religioso e discorso cristiano su Dio, in Il relativismo religioso ..., p. 91-92.

${ }^{23}$ This is why a film attempting a graphic description of the Passions of Christ, justly called terrible (in Orthodox ritual books), was met with harsh criticism by the viewers.

${ }^{24}$ P. Lakeland, op. cit., p. 41, translated into English after the Romanian version of the text.

${ }^{25}$ Hervé Carrier, S.J., Evangelizing the Culture of Modernity, Maryknoll, New York, Faith and Culture Series, Orbis Books, 1993, p. 134.
} 
subject into a confessional one, which should thus be studied in worship places, not schools. The so-called indoctrination was proved to be a groundless accusation, by presenting the curriculum and textbooks where all religions and denominations are described in a tolerant manner. It was not enough.

A hybrid subject was suggested, with the actual intention of pleading against religious faith and criticize it vehemently, whatever its form. These adverse voices are constantly present in the Romanian society and are highly advertised, with obvious manipulatory intentions. Recently, they achieved a major legislative change, aiming to increase the bureaucratic volume of red tape involved in the study of religion, and to delimit it from the other disciplines. We witness the attempts at erosion, pursuing a change in collective mentality, by attracting as many opponents as possible most of them easily influenced persons, unable to defend their position with arguments. In this case, the Romanian Patriarchate has sought, by all specific means, to make its voice heard, warning against the dangers threatening secularized society. Religion textbooks were improved, as well as the topics included in the curriculum, and the teachers of religion were carefully selected, to carry out this activity with passion and missionary zeal. Through dialogues ${ }^{26}$ started by the Romanian Patriarchate, all acknowledged denominations of Romania, except for Jehovah's Witnesses, have joined their efforts to provide theological education in schools, by means of Religion classes, thus giving a chance to the future.

26 See: David Pestroiu, „Religious Dialogue in Postmodernity-Necessity, Chances, Perspectives, in: International Journal of Orthodox Theology 4:1 (2013), p. 151-165. 


\section{Postmodernity-a challenging era for Church mission. Possible solutions and perspectives. Conclusions}

According to P. Lakeland, there are, ultimately, only two ways for the Christian Churches to interact with the postmodern world: they can either convert it to Christ, or not ${ }^{27}$. Obviously, the former way is pursued: it is a difficult process, and theologians themselves are called to use the resources made available by the new technologies and means of communication, in order to achieve it. To the angel's question: Why seek you the living among the dead? (Lk. 24:5), the Church has the chance to provide the answer of eternity, of meta-history, in the universal Kingdom of God whose beginnings are here, in this world so full of imperfections and controversies. It must equip its members with the resources needed to overcome the current challenges, in an integrative manner, rather than an elitist and exclusivistic one ${ }^{28}$, since the mission of the Church is, in fact, the mission of God.

Globalization has opened borders and encouraged travelling. Orthodoxy owns true treasures of spirituality, which are made known by organizing trips and pilgrimages to monasteries and holy places, camps for children and youth, during which the participants do not simply admire museum collections, but foster their veneration for the holy relics, wonder-working icons, places where the divine grace is manifest. These events are occasions for conversations with great spiritual directors, catechetic and missionary programs, cultivating love for prayer and life in the liturgical spirit of Orthodox apophaticism.

${ }^{27}$ P. Lakeland, op. cit., p. 112, translated into English after the Romanian version of the text.

${ }^{28}$ David Fergusson, Church, State, and Civil Society in the Reformed Tradition, in: Wallace M. Alston jr., and Michael Welker, Reformed Theology: Identity and Ecumenicity, Michigan/Cambridge, U.K., Grand Rapids, Wm. B. Eerdmans Publishing Company, 2003, p. 125. 
Orthodoxy opposes the individualism, callousness and indifference of postmodern world, by calling us to aid the afflicted fellow people, and developing special charity programs: canteens for the poor, homes for the elderly, orphanages, after-school and kindergarten programs, etc. The parishes constantly identify and aid those who bear the image of Christ as the least of these brothers and sisters (Matth. 25:40), those who live in suffering and poverty.

The new technologies, especially the communication media, provide excellent opportunities for mission today. The Internet supplies plenty of information on the life of the Orthodox churches, doctrinal issues, moral norms or ritual practices. There are also networks of church mass-media: news agencies, press platforms, TV and radio stations ${ }^{29}$, as well as priests and theology professors who are very admired by the youth (Rev. Assoc. Prof. Gh. Holbea in Bucharest, Rev. Assoc. Prof. Constantin Necula in Sibiu, and so on), and meritoriously carry out spiritual counselling.

Self-defence is a well-established constituent of the Orthodox ecclesial mission. Firstly, it concerns its apologetic aspect, namely the set of values of the faith that must be defended against its detractors, especially nihilists, atheists, disparagers and those who fuel the fake conflict between theology and science. A second direction, equally important, is that of the dialogue with other religions, which carry out a less aggressive proselytism but are dominant in the territories bordering the Orthodox-majority areas, which often generates dramatic conflicts (see the fights between Greeks and Turks, those in the former Yugoslavia, as well as the recent wave of Muslim migrants in Europe). A third direction is the defence against the proselytism of the new religious movements, extremely aggressive towards Orthodox Christianity, especially of late.

${ }^{29}$ The Romanian Orthodox Church owns the Trinitas TV and Radio stations, broadcasting 24 hours a day, with national coverage by cable and satellite. 
The old Christian apologies written during persecutions, in order to demonstrate the superiority of Christianity over paganism, are more topical than ever. We now witness the attack of neopaganism, under manifold guises: from the revival of old idolatrous beliefs (druidism, bogomilism etc.) to the creation of new idols, on the foundations provided by (post)modern emancipations. In addition, many attacks are launched against traditional Christianity, as atheism and nihilist ideologies break out afresh. It is the merit of Orthodox missiology that it supports, in every possible way, the dialogue between theology and science in view of their reconciliation. The Orthodox centers dedicated to this type of dialogue, are supported and encouraged to provide the background for an integrative, motivating vision of theological and cosmological phenomenology, perceived not as disjunction, but as synergic work. The mondialization of crises calls for the universalization of solidarity $^{30}$ - justly states Rev. Phd. Prof. Teofil Tia.

Traditional Churches, and especially the Orthodox Church, insist on the importance of keeping alive the manifest expressions of religiosity, which bring man closer to God, bring peace and serenity in his life, and provide it with meaning: the pursuit of blissful eternity. To foster piety and maintain devotion, Romanian Orthodoxy stresses the importance of spiritual life, of hesychast asceticism, which illustrates the power of prayer in human life. Monasteries are true oases, maintaining and cultivating a lifestyle away from the world, yet anchored in its realities, offering spiritual remedies against the challenges of secularism. Also, introducing the spirit of prayerfulness and liturgical chanting in people's homes, cars or workplaces, through the Trinitas Radio and TV stations owned by the Romanian Orthodox Church, maintains a religious state of piety, reminding that the goal and role of human life is closeness to God.

\footnotetext{
${ }^{30}$ Teofil Tia, Descreştinarea - o ,,apocalipsă a culturii (Dechristianization an ,, apocalypse of culture), Alba Iulia, Reîntregirea Publishing House, 2009, p. 489.
} 
The most important field of domestic ecclesial missionary activity is the educational one. Educating the young generations by religious training and putting moral norms into practice in one's own life, aiming for perfection, is a constant concern of the Church. Orthodoxy emphasizes the importance of the educational factor not only in its catechetical aspect, in the worship places, but also in the public or private schools. The churches carry out both programs dedicated to the little ones (Christ shared to the children) and to adults (The Way). In schools, religious-moral formation is constant and continuous, according to clearly-defined curricular plans. There is also individual catechesis, by the spiritual guidance provided in the Mystery of Confession - an extremely effective form of religious education. All this aims to achieve the desired spiritual progress, the ascension on the Ladder of perfection, to turn our postmodern fellow people, from robot-like manipulated individuals into free, responsible persons, committed to the salvation of their souls.

\section{References}

1. Barnes, Michael, Christian Identity and Religious Pluralism: Religions in Conversation, Nashville, Tennessee, Abingdon Press, 1989.

2. Carrier, Hervé S.J., Evangelizing the Culture of Modernity, Maryknoll, New York, Faith and Culture Series, Orbis Books, 1993.

3. Davie, Grace, Religion in Britain Since 1945: Believing without Belonging, Oxford, Institute of Contemporary British History, Blackwell, 1995.

4. Dotolo, Carmelo, Un cristianesimo possibile. Tra postmodernità e ricerca religiosa, Brescia, Editrice Queriniana, 2007.

5. Fergusson, David, Church, State, and Civil Society in the Reformed Tradition, in: Wallace M. Alston jr., and Michael Welker, Reformed Theology: Identity and Ecumenicity, Michigan/Cambridge, U.K., Grand Rapids, Wm. B. Eerdmans Publishing Company, 2003.

6. Grenz, Stanley J., A primer on postmodernism, Michigan/ Cambridge, U.K., Grand Rapids, William B. Eerdmans Publishing Company, 1996.

7. Guiness, Os, Mission modernity: seven checkpoints on mission in the modern world, in: Philip Sampson, Vinay Samuel and Chris Sugden 
(editors), Faith and Modernity, Oxford, Regnum Books International, 1997.

8. Himcinschi, Mihai, Violența. O analiză misionară şi teologică (Violence. A missionary and Theological Approach), Alba Iulia, Reîntregirea Publishing House, 2010.

9. Lakeland, Paul, Postmodernity: Christian Identity in a Fragmented Age (Guides to Theological Inquiry Series), Minneapolis, Minnesota, Fortress Press, 1997.

10. Lyotard, Jean François The Postmodern Condition: a Report on Knowledge,translation from French byGeoff Bennington and Brian M assumi, Foreword by Fredric Jameson, Minneapolis, University of Minnesota Press, 1984.

11. Maccari, Carlo, Aspetti relativistici dello gnosticismo e della „New Age, in: Il relativismo religioso sul finire del secondo millennio, Gruppo di ricerca e di informazione sulle Sètteretariato per l'ecumenismo e il dialogo della Conferenza episcopale italiana, Citta del Vaticano, Universita Cattolica del Sacro Cuore - Libreria Editrice Vaticana, 1996.

12. Mantzaridis, Georgios I., Globalizare şi universalitate. Himeră şi adevăr (Globalization and universality. Delusion and truth), Bucharest, Bizantină Univerity Press, 2002.

13. Meliton of Chalcedon, The Ecumenical Movement and the Fourth General Assembly of the WCC at Uppsala, in: The Orthodox Church in the Ecumenical Movement. Documents and Statements, 1902-1975, edited by Constantin G. Patelos, Geneva, World Council of Churches, 1978.

14. Neamţu, Mihail, Bufniţa din dărâmături; Insomnii teologice în România postcomunistă (An Owl among the Ruins. Theological Insomnias in Post-Communist Romania), 2-nd edition, revised and enhanced, Iaşi, Polirom Publishing House, 2008.

15. Pestroiu, David, Religious Dialogue in Postmodernity - Necessity, Chances, Perspectives, in: International Journal of Orthodox Theology 4:1 (2013), p. 151-165.

16. Pestroiu, David, Misiunea Bisericii Ortodoxe in postmodernitate (The Mission of the Orthodox Church in Postmodernity), in: Theologia Pontica, Year II (2009), no. 1.

17. Petraru, Gheorghe, Teologie fundamentală şi misionară. Ecumenism (Fundamental and Missionary Theology. Ecumenism), Iași, Performantica Publishing House, 2006. 
18. Rice, Jesse, The Church of Facebook. How the Hyperconnected are Redefining Community, published by David C. Cook, Colorado Springs, 2009.

19. Salvati, G. Marco, Relativismo religioso e discorso cristiano su Dio, in: Il relativismo religioso sul finire del secondo millennio, Gruppo di ricerca e di informazione sulle Sètteretariato per l'ecumenismo e il dialogo della Conferenza episcopale italiana, Citta del Vaticano, Universita Cattolica del Sacro Cuore - Libreria Editrice Vaticana, 1996.

20. Smith, Pam, Online mission and ministry. A theological and practical guide, London/Hong Kong, Society for Promoting Christian Knowledge, Ashford Colour Press, 2015.

21. St Gregory Palamas, Despre lumina şi luminarea dumnezeiască (On divine light and enlightening), in: Dumitru Stăniloae, Viaţa şi invăţătura Sfântului Grigrie Palama (The Life and Teachings of St Gregory Palamas), Bucharest, The Biblical and Missionary Institute of the Romanian Orthodox Church Publishing House, 2006.

22. Tia, Teofil, Descreştinarea - o ,apocalipsă a culturii (Dechristianization - an ,apocalypse of culture), Alba Iulia, Reîntregirea Publishing House, 2009.

23. World Council of Churches - Mission and Evangelism, Believing without belonging? In search of new paradigms of church and mission in secularised and postmodern contexts, Consultation in Breklum, Northern Germany, 2002 http://www.oikoumene.org/en/resources/documents/commissions/missi on-and-evangelism/consultation-on-mission-in-secularised-andpostmodern-contexts 